\title{
An early description of Hematuria in Medieval Persia: a letter to the editor
}

\author{
Ali Aminian ${ }^{1}$, Ehsan Zaboli², Seyde Sedighe Yousefi ${ }^{3}$
}

${ }^{1} \mathrm{PhD}$ Candidate in Persian Medicine, Department of Traditional Persian Medicine, Faculty of Medicine, Mazandaran University of Medical Sciences, Sari, Iran

${ }^{2}$ MD, Oncologist, Assistant Professor, Gastrointestinal Cancer Research Center, Mazandaran University of Medical Sciences, Sari, Iran

${ }^{3}$ MD, PhD, Assistant Professor, Department of Traditional Persian Medicine, Faculty of Medicine, Mazandaran University of Medical Sciences, Sari, Iran

Type of article: Letter to editor (LTE)

\begin{abstract}
Hematuria is one of the most important clinical manifestations, dating back in antiquity to more than a thousand years ago. In this paper, we tried to give a brief history of hematuria in Persian medicine and compare its similarities with Modern medicine. The importance of this issue is to give a better cognition of hematuria in the Persian medicine viewpoint in comparison with Modern medicine and also to understand the antiquity of hematuria, using simple and accessible therapies, provide a background for further studies in this field, and ultimately help improve Modern medicine in order to have a better treatment package, along with managing the costs.

Keywords: Urine; Hematuria; Modern medicine; Persian medicine
\end{abstract}

\section{Abbreviations / Acronyms:}

CAM: Complementary and Alternative Medicine; GU: Genitourinary Tract; PM: Persian Medicine; UA: Urine Analysis

\section{Introduction \\ Dear Editor,}

In the past centuries, urine as one of the most prominent waste body-fluids, has been extensively used by physicians for a precise diagnosis and prognosis (1). Persian medicine (PM) as one of the ancient branches of complementary and alternative medicine (CAM) and its outstanding medical scholars, especially in the golden age of Islam ( $\left(^{\text {th }}\right.$ to $12^{\text {th }}$ century AD), have emphasized the importance of urine analysis (UA) $(2,3)$. PM scholars count on urine as a whole body scanner, due to the capability of circulation between different organs. The urine, in PM resources, was nominated with different names such as the "bowl" (meaning waste body fluid), "Tafsere" (meaning commentator on body and organ tracts' condition), and "Dalil" (Meaning that which expresses the cause or sign), due to its importance $(1,4)$. In PM manuscripts, in order to perform a standard urine analysis, the patient should collect all his/her morning urine volume accumulated in the bladder, in a clean, transparent, bladder-shaped glass container named "Gharoore" (Phial, which is also an accepted synonym for urine in PM), according to the belief of PM scholars that a more accurate diagnosis would arise if the total morning urine volume could form in a bottle in the same way that it was formed in the bladder. Then the collected urine specimen was analyzed within six hours of collection by the physician in seven features including color, consistency, purity and turbidity, sediment, scarcity and abundance, odor, and froth $(\mathrm{Zabad})(5,6)$. Meanwhile, a change in the urine color to red in the form of

\section{Corresponding author:}

Assistant Professor Dr. Seyde Sedighe Yousefi, Department of Traditional Persian Medicine, Faculty of Medicine, Mazandaran University of Medical Sciences, Sari, Iran.

Tel: +98-11-33252843,+98-9113903029, Fax:+98-11-33244893, E-mail: s.yousefi@mazums.ac.ir

Received: February 14, 2019, Accepted: April 20, 2019, Published: June 2019

iThenticate screening: April 22, 2019, English editing: April 25, 2019, Quality control: April 25, 2019

This article has been reviewed / commented by five experts

(C) 2019 The Authors. This is an open access article under the terms of the Creative Commons Attribution-NonCommercialNoDerivs License, which permits use and distribution in any medium, provided the original work is properly cited, the use is non-commercial and no modifications or adaptations are made. 
"Hematuria" is one of the most key issues in interpreting the results of urine analysis, which has always been under consideration of the Persian medicine experts (1). In Modern medicine, hematuria is defined as the presence of blood in the urine, which may be detected frequently in periodic screening tests or may be visible as frank blood (7). In PM resources, hematuria known as the term "Bowl-al-Dam" (Khoon-Raftan), means blood voiding, slightly or instantly and bulky, which is different from another term named as "Bowl-e-Damavi" (Bloody urine), means urine contaminated with some amount of blood (8). Also in PM, similar to Modern medicine, hematuria is one of the most important signs and symptoms of the genitourinary tract (GU), which plays an important role in prognosis and diagnosis of diseases within or outside the GU system $(1,7)$. As in Modern medicine, the causes of hematuria are separately mentioned in Persian medicine, and are compared in Table 1, which shows similarities between the two.

Table. 1 Comparison of the causes of hematuria between Persian medicine and Modern medicine

\begin{tabular}{|l|l|}
\hline Causes of hematuria in Persian medicine $(2,3,5,8)$ & $\begin{array}{l}\text { Causes of hematuria in modern medicine } \\
(9)\end{array}$ \\
\hline $\begin{array}{l}\text { Corrosion, along with vaginal discharge in the urinary tract (Taakkol- } \\
\text { e-Oroogh va Bowl ba Rim) }\end{array}$ & Urinary tract infection (UTI) \\
\hline Poor kidney performance (Zaaf-e Gorde) & Renal failure \\
\hline $\begin{array}{l}\text { Heavy lifting, falling down, blunt trauma (Bardashtan-e chizi Geran, } \\
\text { Saghate, Jahidan az jaa, Zarbeh) }\end{array}$ & $\begin{array}{l}\text { Exercise-induced hematuria and blunt } \\
\text { trauma caused hematuria }\end{array}$ \\
\hline $\begin{array}{l}\text { Consumption of foods or drugs with hot temperament (Mizaj), } \\
\text { (Tanavol-e-Aghziye tond ya Advieh garm) }\end{array}$ & Food or drug-related hematuria \\
\hline Hard nodes swelling & Lymphoma \\
\hline Excessive blood concentration (Emtela e-Dam) & Hematologic abnormalities \\
\hline Liver malfunction (Zaaf-e kabed) & Liver failure \\
\hline Renal stone & Urinary calculi \\
\hline GU tissue tight swelling (Owram-e-Solb) & GU tumors \\
\hline Wounding of the kidney & $\begin{array}{l}\text { Instrumentation or surgery trauma, } \\
\text { penetrating trauma caused hematuria }\end{array}$ \\
\hline $\begin{array}{l}\text { Irritation and stretching of the urinary tract due to cold and dry } \\
\text { distemperament (Su-e-Mizaj Sard-o- Khoshk va Tamaddod) }\end{array}$ & Urethral stricture \\
\hline $\begin{array}{l}\text { Irritation and stretching of the urinary tract due to cold and dry } \\
\text { distemperament (Su-e-Mizaj Sard-o-Khohsk va Tamaddod) }\end{array}$ & Ureteropelvic junction obstruction \\
\hline $\begin{array}{l}\text { Dilatation or splitting of kidney vessels (Goshad Shodan ya } \\
\text { Shekaftan Oroogh) }\end{array}$ & Vessels aneurysm or Malformation \\
\hline
\end{tabular}

In Persian Medicine, the most important causes of hematuria include poor kidney performance, liver malfunction, and dilatation or splitting of the GU tract vessels for a variety of reasons such as heavy lifting, blunt trauma, fallingdown and corrosive infections. Less important causes of hematuria also include renal stones, tight swellings of GU tissue (Owram-e-Solb), dilatation, varicosity or splitting of GU vessels, dryness and fragility of GU tract mucous membrane due to cold and dry distemperament (Su-e-Mizaj) and consuming excessive foods or drugs with hot and dry temperament (Mizaj) like spearmint (Mentha spicata) $(2,3,5,8)$. According to PM resources, treatments also based on a therapeutic package which respectively consist of lifestyle modification including nutritional diet, drug prescription and ultimately, manual maneuvers such as cupping, venesection, and surgery. Fortifying the kidney and liver with tonic medications and eventually cupping the pubic area, are some of the most common treatments of controlling hematuria in PM $(2,3,5,8)$. Understanding the antiquity of hematuria and attending to the similarities between Persian medicine and Modern medicine in diagnosis and treatments, may finally help the health system in using simple and accessible therapies, provide a background for further studies in this field, and ultimately aid better management, and treatment costs.

Acknowledgments:

This article is based on a Ph.D. thesis processed by Ali Aminian and with thesis No. 2345, sponsored by Mazandaran University of Medical Sciences, Sari, Iran.

\section{Conflict of Interest:}

There is no conflict of interest to be declared. 


\section{Authors' contributions:}

All authors contributed to this project and article equally. All authors read and approved the final manuscript.

\section{References:}

1) Shamsi M, Haghverdi F, Ashtiyani SC. A brief review of Rhazes, Avicenna, and Jorjani's views on the diagnosis of diseases through urine examination. Iran J Kidney Dis. 2014; 8(4): 278-85.

2) Avicenna. The Canon of Medicine [Al-Qanoon fi al-Tibb]. Beirut; Lebanon. Dar Ihyaa al-Turrath al-Arabi. 2005; 3: 400-3.

3) Rhazes M. The Liber-continents [Al-Hawi al-Kabir fi al-Tibb]. 2th edition, Beirut; Lebanon. Dar Ihyaa alTurrath al-Arabi. 2002; 10: 231-46.

4) Changizi Ashtiyani S, Cyrus A. Rhazes, a genius physician in diagnosis and treatment of kidney calculi in medical history. Iran J Kidney Dis. 2010; 4(2): 106-10. PMID: 20404418.

5) Jorjani SE. Treasure of Khwarazm Shah [Zakhireye Khwarzam Shahi]. Edited by Sirjani S. Tehran: Bonyad-e Farhang-e Iran. Iran. 1976.

6) Tadjbakhsh H. Sayyed Esma'il Jorjani, founder of Persian medicine. J Vet Res. 2007; 62(4): 131-40.

7) Fickenscher L. Evaluating adult hematuria. Nurse Practitioner. 1999; 24(9): 58. doi: 10.1097/00006205199909000-00005. PMID: 10507071.

8) Cheshti MA. The Great Elixir [Exire-e-Azam], facsimile edition, 2nd ed. Iran; Tehran: Research Institute for Islamic and Complementary Medicine (RICM). 2007; 2: 521-6.

9) Patel JV, Chambers CV, Gomella LG. Hematuria: etiology and evaluation for the primary care physician. Can J Urol. 2008; 15(Suppl 1): 54-61. PMID: 18700066. 